\title{
Redescriptions of Two Ampithoid Amphipods, Ampithoe lacertosa and $A$. tarasovi (Crustacea: Amphipoda), from Korea
}

\author{
Myung-Hwa Shin, Ji Sun Hong and Won Kim* \\ School of Biological Sciences, Seoul National University, Seoul 151-747, Korea
}

\begin{abstract}
Two ampithoid species, Ampithoe lacertosa Bate and A. tarasovi Bulycheva, are redescribed. A. tarasovi has been misidentified as A. lacertosa in Korea. A. tarasovi can be distinguished from A. lacertosa in having the following characteristics: the apical and medial lobes of outer lobe are separated in the lower lip, the carpus of male gnathopod 1 is about 1.4 times as long as the propodus, the palm of male gnathopod 2 has a sloped quadrate hump and a posterodistal tooth, the peduncle of uropod 3 is approximately 2 times as long as the rami, and the length of the carpus is longer than that of the propodus of female gnathopod 1 . This study provides detailed descriptions and figures for both species. A. tarasovi is reported for the first time as a member of the Korean fauna.
\end{abstract}

Keywords: redescription, Ampithoe lacertosa, Ampithoe tarasovi, misidentification, Ampithoidae, Amphipoda, Korea

\section{INTRODUCTION}

Ampithoid amphipods are herbivorous amphipods that live in algae and seagrass worldwide (Poore et al., 2008). They are ecologically important members of the marine community and play roles as both consumer and prey in the marine food web. The genus Ampithoe Leach, 1814, a member of the family Ampithoidae, is the most speciose genus and includes 79 species worldwide (Peart, 2007). The most important taxonomic traits of the members of this group are associated with the second gnathopod. The appendages appear to have strong sexual dimorphism and variation during developmental stages.

To date, seven species of the genus Ampithoe have been reported from Korea (Kim and Kim, 1988). During a recent taxonomic revision of the genus Ampithoe, we became aware that Ampithoe tarasovi Bulycheva, 1952 was frequently confused with A. lacertosa Bate, 1858 in Korea. Accordingly, we reexamined some of the specimens that were deposited at the Seoul National University after descriptions were provided by $\operatorname{Kim}$ and $\operatorname{Kim}(1987,1988)$. We identified specimens of $A$. tarasovi that were the previously identified as $A$. lacertosa. Here, we present the redescriptions of $A$. tarasovi and $A$. lacertosa based on morphological characteristics. $A$. tarasovi is reported for the first time as a member of the Korean fauna.

\footnotetext{
*To whom correspondence should be addressed

Tel: 82-2-880-6695, Fax: 82-2-872-1993

E-mail: wonkim@plaza.snu.ac.kr
}

\section{MATERIALS AND METHODS}

Our specimens were collected from Korea between 2006 and 2009. The specimens were collected among algae in tide pools, intertidal zones, and subtidal zones. The specimens were preserved in $95 \%$ ethanol. A stereomicroscope (Leica MZ8) and a compound microscope (Olympus BX50) were used to observe the specimens. The dissection and mounting methods followed Barnard and Karaman (1991). The illustrations were made using a drawing tube or camera lucida. The body length was measured from the tip of rostrum to the posterior end of urosomite 3 . All specimens examined in the present study were deposited in the Marine Arthropod Depository Bank of Korea (MADBK), Seoul National University.

\section{SYSTEMATIC ACCOUNTS}

Family Ampithoidae Stebbing, 1899

Genus Ampithoe Leach, 1814

Ampithoe lacertosa Bate, 1858 (Figs. 1-3)

Amphithoe lacertosa Bate, 1858: 362; Bate, 1862: 236, pl.

41, fig. 5; Gurjanova, 1951: 895, fig. 622.

Ampithoe lacertosa: Barnard, 1954: 31, pls. 29-30; Barnard,

1965: 9, figs. 4-5; Conlan and Bousfield, 1982: 47, fig. 2;

Nagata, 1960: 175, pl. 16, figs. 95-96; Kim et al., 2005: 2. Ampithoe macrurus Stephensen, 1944: 80, figs. 30-31.

Material examined. Specimens from Kim and Kim (1988): 
$1 \sigma^{7}, 3$ 우 우, Haeundae, Haeundae-gu, Busan-si, 27 Jul. 1976; $2^{7}$ 지, 3 우 우, Gadeokdo, Gangseo-gu, Busan-si, 23 May 1978; 1 ㅈ, 3 우 우, Nokdong, Doyang-eup, Goheung-gun, 18 Jun. 1980; 2 ఠ $^{\nearrow}, 2$ 우 우, Guryongpo, Pohang-si, 10 Aug. 1982; 1 ð, Seonyudo, Okdo-myeon, Gunsan-si, 7 May 1986. Specimens collected in this study: 3 우 우, Hyeonpo-ri, Bukmyeon, Ulleung-gun, 19 Jun. 2006; $2 \sigma^{\nearrow} \sigma^{\nearrow}, 1$ 우, Hamo beach, Daejeong-eup, Namjeju-gun, 30 May 2007; $1 \sigma^{7}$, Dongdo, Dokdo-ri, Ulleung-eup, Ulleung-gun, 23 Jun. 2007; $3 \sigma^{7} \sigma^{7}$, 5 우 우, Seokpo-ri, Hacheong-myeon, Geoje-si, 23 May 2008; 11 지 저, 8 우 우, Kyokpo, Byeonsan-myeon, Buan-gun, 17 Apr. 2009; 2 『 Љ 5 우 우, Mosa beach, Gogun-myeon, Jindo-

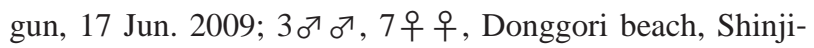
myeon, Wando-gun, 18 Jun. 2009; 3 우 우, Balpo beach,

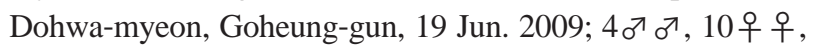
Dukheung beach, Dongil-myeon, Goheung-gun, 19 Jun. 2009; 4 저 저, 7 우 우, Bangjukpo beach, Jukpo-ri, Dolsan-eup, Yeosu-si, 20 Jun. 2009; 8 지 శ, 17 우 우, Museulmok beach, Pyeongsa-ri, Dolsan-eup, Yeosu-si, 20 Jun. 2009; $4 \sigma^{\nearrow} \sigma^{\top}$, 5 우 우, Kkaedol (SCUBA), Yeonji-ri, Uljin-eup, Uljin-gun, 1

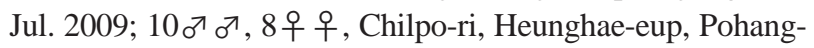
si, 11 Jul. 2009.

Male. Body (Fig. 1A) $21.2 \mathrm{~mm}$ long, evenly covered with light spots entirely. Eye black. Antenna 1 (Fig. 1B) about 0.8 times as long as body; peduncular article 1 bearing 5 spines on posterior margin; peduncular article 2 slightly longer than article 1. Peduncular article 4 of antenna 2 (Fig. 1C) longer than article 5 and gradually broadened distally. Peduncular article 2 of antenna 1 reaching nearly middle part of article 4 of antenna 2.

Upper lip (Fig. 1D) broadened, with ventral margin rounded. Right incisor of mandible (Fig. 1F) with 8 teeth, left incisor (Fig. 1E) with 8 teeth; right lacinia mobilis with 6 teeth, left lacinia mobilis with 5 teeth; bearing 9 right raker spines and 8 left raker spines; molar well developed, triturative, bearing 2 long serrate setae; article 3 of palp longer than article 2. Apical lobe of outer lobe in lower lip (Fig. 1G) about 3 times as long as medial lobe and both lobes well separated.

Inner plate of maxilla 1 (Fig. $1 \mathrm{H}$ ) having 1 seta; outer plate with 10 apical spines; article 2 of palp with 10 apicomedial spines and 7 subterminal setae. Inner plate of maxilla 2 (Fig. 1I) narrowed; outer plate broader.

Outer plate of maxilliped (Fig. 1J) having 18 teeth; article 1 of palp identical to article 3 in length, article 4 with 2 setae on inner margin.

Gnathopod 1 (Fig. 2A) subchelate; coxa broadened, anteroventral margin produced and rounded; basis having anterodistal lobe; merus shorter than propodus; carpus slightly longer than propodus, having posterodistal lobe; propodus subrectangular; palm oblique. Gnathopod 2 (Fig. 2B) chelate; coxa subrectangular; basis more expanded than in gnathopod 1, having anterodistal lobe; ischium having anterodistal lobe; merus and carpus identical in length; carpus having subtriangular lobe on posterior margin; propodus subrectangular, about 2.6 times as long as carpus, posterior margin greatly extended; palm transverse, posterodistal edge downwardly produced and subpointed; dactylus slender and strongly curved.

Pereopods 3 (Fig. 2C) and 4 (Fig. 2D) nearly identical in shape. Coxa of pereopod 3 deeper than wide, with anteromedial margin produced; ischium 0.5 times as long as carpus; carpus and propodus nearly identical in length. Basis of pereopod 5 (Fig. 2E) ovoid; merus nearly identical to propodus in length; carpus about 2 times as long as ischium; propodus about 1.3 times as long as carpus, bearing spines on posterior margin. Pereopods 6 (Fig. 2F) and 7 (Fig. 2G) nearly identical in shape. Basis of pereopod 7 slender, bearing spines on anterior margin and 1 spine on posteroventral corner; merus about 3 times as long as ischium; carpus shorter than merus; propodus about 1.3 times as long as carpus, bearing spines on anterior margin.

Epimera 1-3 (Fig. 3A) with lateral ridge; epimeron 1 rounded posterodistally, having small tooth on posteroventral angle; epimera 2 and 3 subrounded posterodistally, with ventral margin evenly curved, and having rounded tooth on each posteroventral angle.

Uropod 1 (Fig. 3B) with peduncle about 2 times as long as rami; inner ramus longer than outer ramus. Uropod 2 (Fig. $3 C$ ) with peduncle about 1.5 times as long as rami; inner ramus longer than outer ramus. Peduncle of uropod 3 (Fig. 3D) about 3 times as long as rami, bearing 5 dorsal and 5 distal spines; inner ramus slightly longer than outer ramus, bearing 3 dorsal and 5 apical spines; outer ramus with 2 hooklike apical spines and 1 dorsal spine.

Telson (Fig. 3E) entire, broader than long, gradually narrowed distally, nearly truncated, having 2 long subapical setae, and 3-5 smooth and 2 small plumose setae on both sides; telsonic cusps truncated hook-shape, with 1 plumose seta.

Female. Body (Fig. 3F) 20.48 mm long, slightly smaller than that of male.

Gnathopod 1 (Fig. 3G) subchelate; coxa deeper than wide, with anteroventral margin produced and rounded; basis slender, having anterodistal lobe; merus 0.5 times as long as propodus; carpus widened in middle; propodus subrectangular, about 1.2 times as long as carpus; palm oblique; dactylus slightly overreaching palm. Gnathopod 2 (Fig. 3H) subchelate; coxa deeper than wide; merus identical to carpus in length; propodus subrectangular, about 1.7 times as long as carpus; palm oblique; dactylus slightly overreaching palm. Remarks. Ampithoe lacertosa Bate, 1858 is similar to A. 

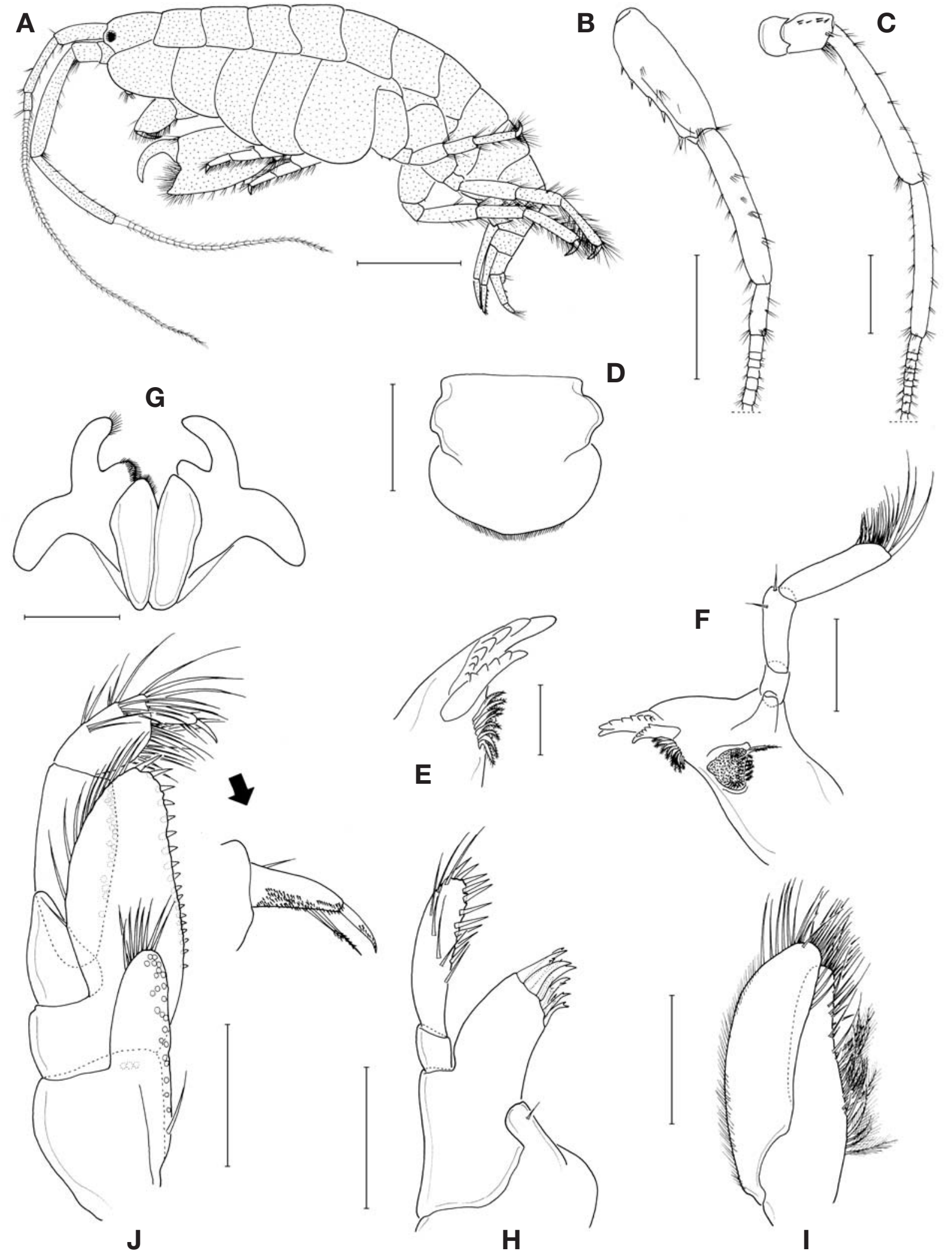

Fig. 1. Ampithoe lacertosa Bate, male. $A$, body; $B$, antenna $1 ; C$, antenna $2 ; D$, upper lip; $E$, left mandible; $F$, right mandible; $G$, lower lip; H, maxilla 1 ; I, maxilla 2; J, maxilliped. Scales: A, 4 mm; B, C, 2 mm; D-J, $0.5 \mathrm{~mm}$. 
Myung-Hwa Shin, Ji Sun Hong and Won Kim

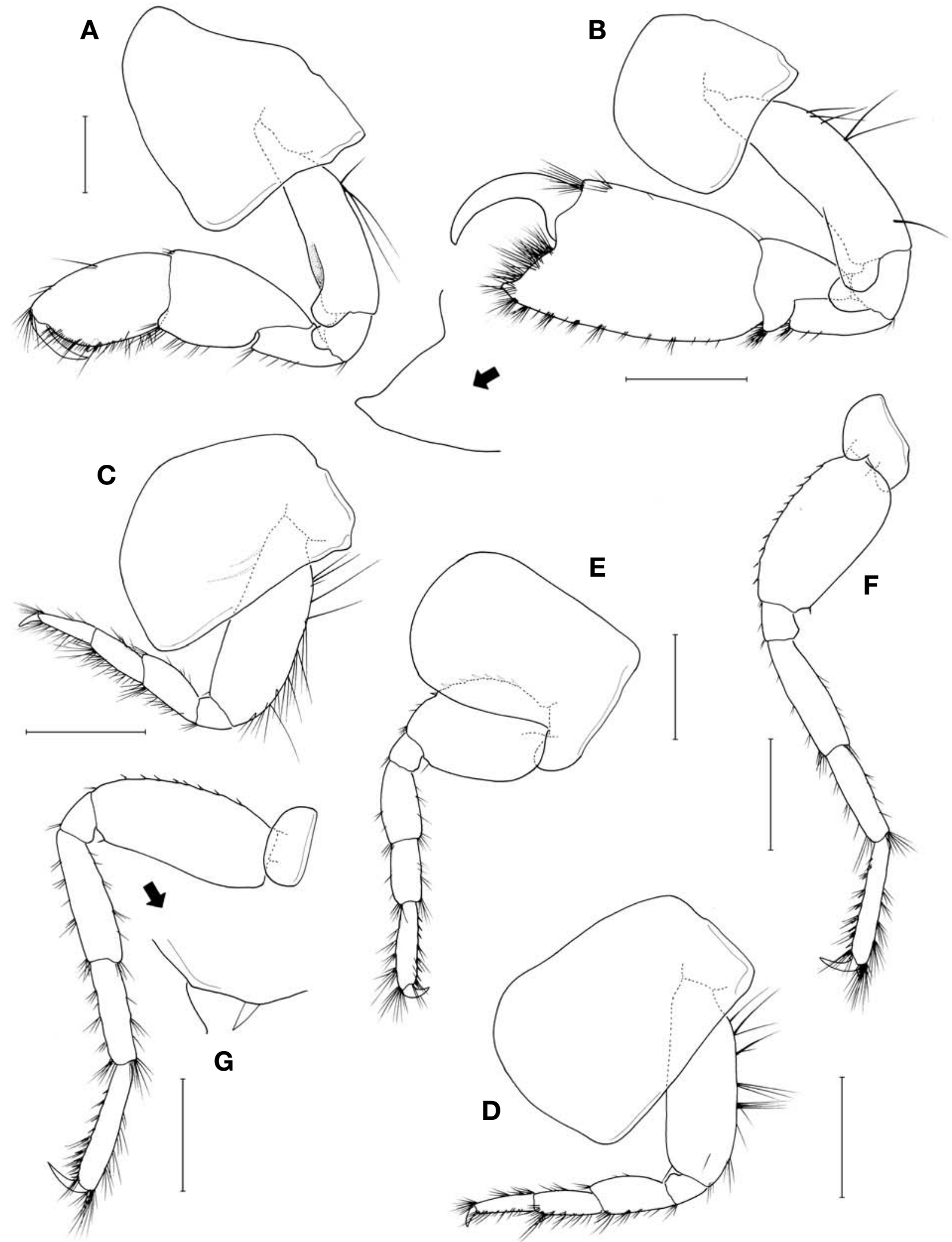

Fig. 2. Ampithoe lacertosa Bate, male. A, gnathopod 1; B, gnathopod 2; C, pereopod 3; D, pereopod 4; E, pereopod 5; F, pereopod 6; G, pereopod 7. Scales: A, $1 \mathrm{~mm}$; B-G, $2 \mathrm{~mm}$. 

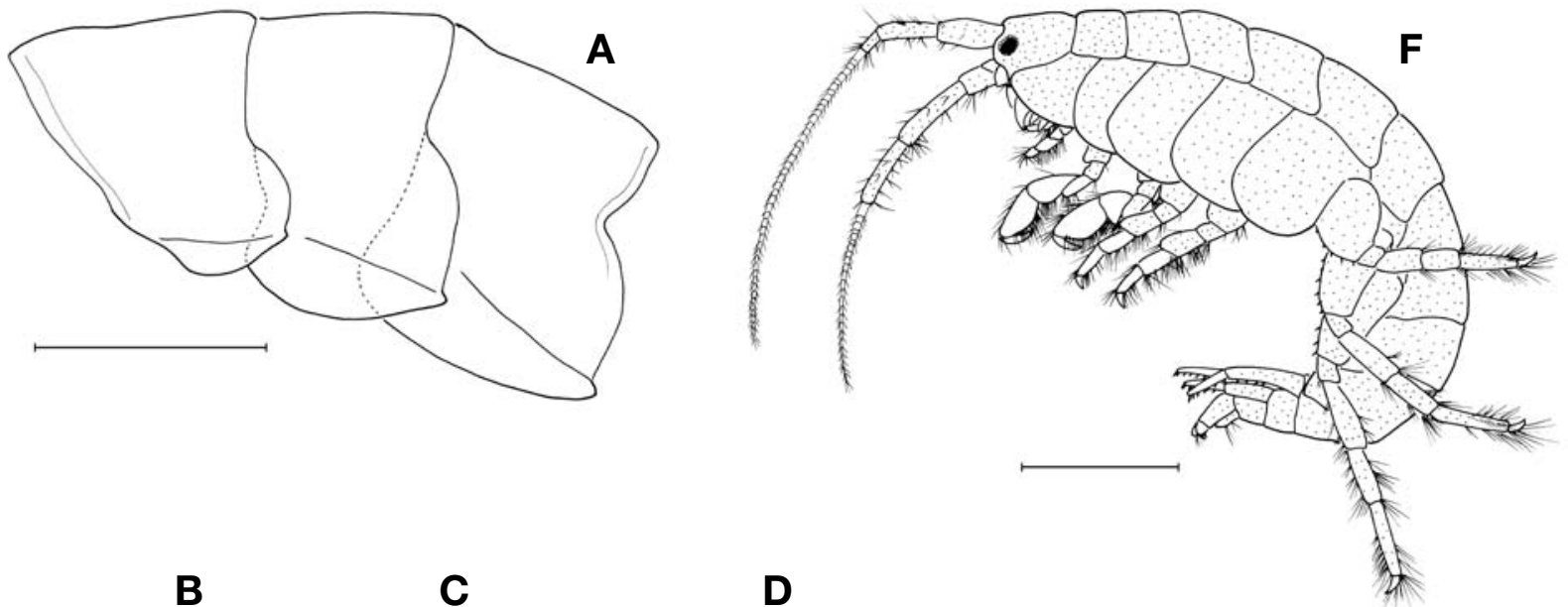

B
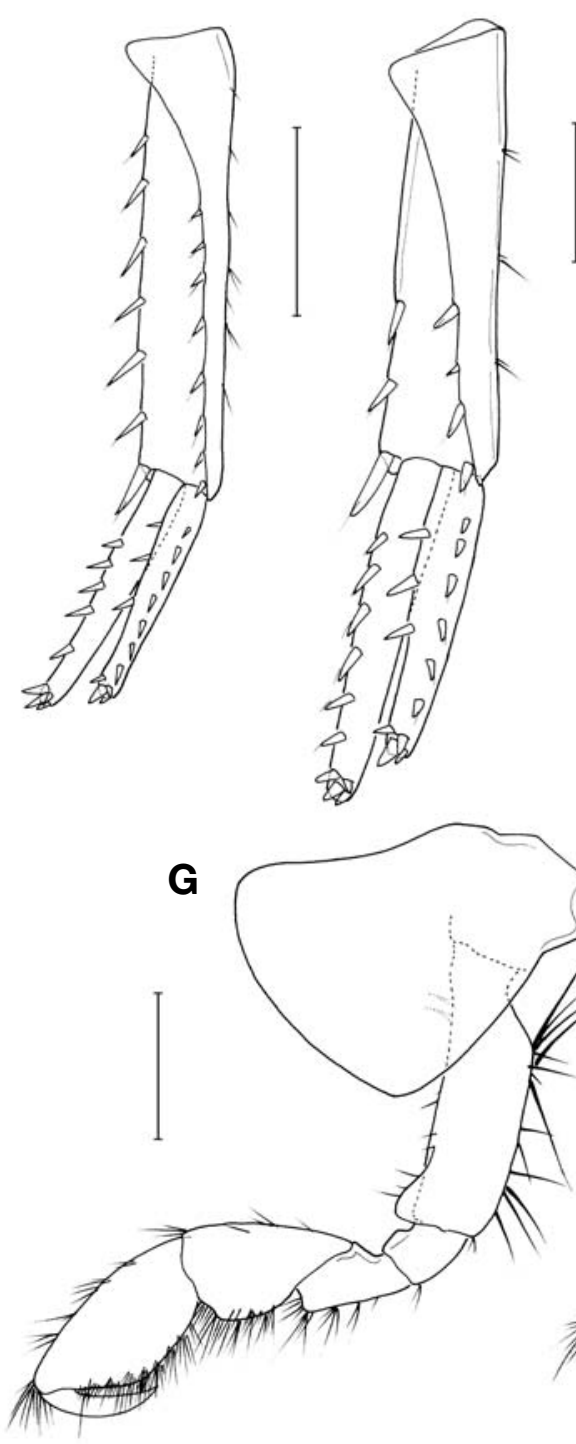
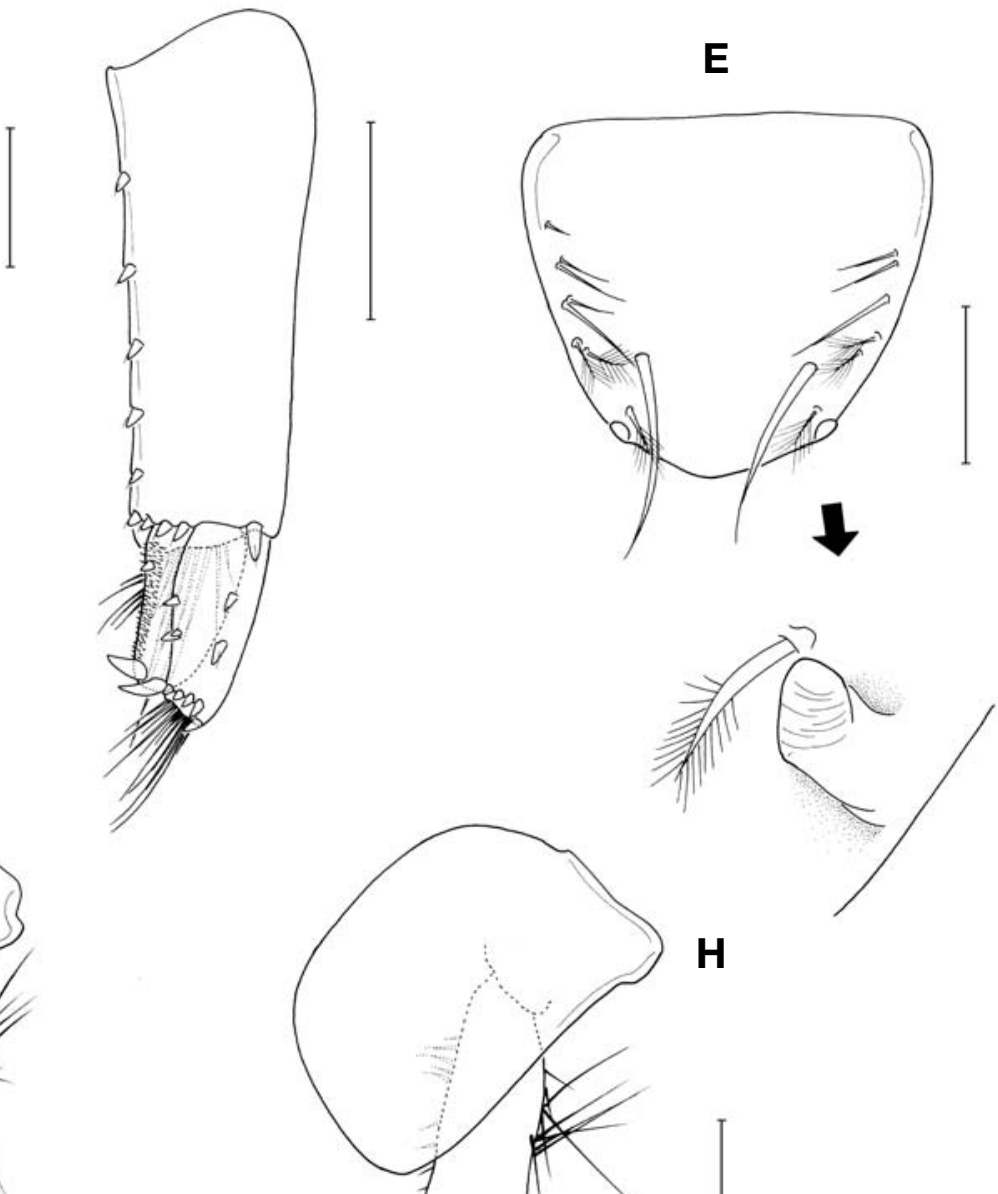
tarasovi Bulycheva, 1952, however, it can be distinguished from A. tarasovi by the following characteristics: (1) well separated outer lobes of lower lip, (2) presence of marginal setae on carpus and propodus of male gnathopod 1, (3) palm bearing a posterodistal edge produced downwardly and without any hump and groove in male gnathopod 2, (4) peduncle of uropod 3 about 3 times as long as rami, and (5) length of propodus longer than that of carpus of female gnathopod 1 .

The original description of Ampithoe lacertosa Bate, 1858 is very brief and not illustrated, and the description of Bate (1862) is also not detailed. However, according to the figures shown in Bate (1862), the gnathopod 2 of male is chelate and the peduncle of uropod 3 is much longer than the rami. Besides, the characteristics of our specimens agree with Barnard's descriptions of A. lacertosa that were published in 1954 and 1965. Conlan and Bousfield (1982) described that A. lacertosa from Northeastern Pacific bears marginal setae on the carpus and the propodus of gnathopod 1, whereas setae are absent as in the present specimens.

This species is distinguished from other species of the same genus in having the following features: the apical and medial lobes of outer lobe are well separated in the lower lip, the posterodistal edge of the palm is extends downwardly in gnathopod 2, the posteroventral angle of epimeron 3 has a distinct tooth, and the peduncle of uropod 3 is about 3 times as long as the rami.

Distribution. Pacific Ocean: Korea, Japan, Alaska, British Columbia, Oregon, and California.

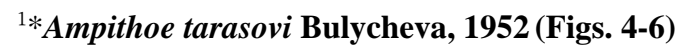

Ampithoe tarasovi Bulycheva, 1952: 246, fig. 38; Tzvetkova, 1967: 190.

Ampithoe lacertosa: Kim and Kim, 1987: 3, fig. 2; Kim and Kim, 1988: 109, fig. 2A [not Ampithoe lacertosa Bate, 1858].

Material examined. Specimens from Kim and Kim (1987): 7 지 지, 10 우 우, Biyangdo, Hanrim-eup, Jeju-si, 2 May 1985. Specimens from Kim and Kim (1988): 3 우 우, Guryongpo, Pohang-si, 10 Aug. 1982; 3 ๙ $^{\nearrow}$, 10 우 우, Guryongpo, Pohang-si, 12 Aug. 1982. Specimens collected in this study: $1 \sigma^{\nearrow}$, Kimnyeong, Guja-eup, Jeju-si, 29 May 2007; 7 ð 3 우 우, Hamo beach, Daejeong-eup, Seogwipo-si, 30 May

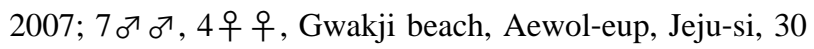

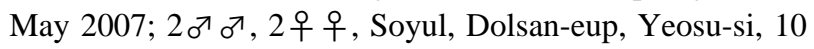
Oct. 2008; 1 우, Dukheung beach, Dongil-myeon, Goheung-

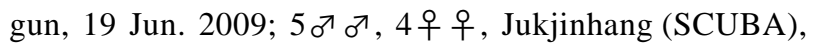

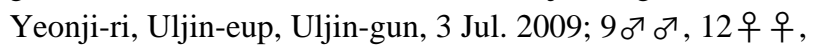
Homigot, Daebo-ri, Daebo-myeon, Pohang-si, 13 Jul. 2009.
Male. Body (Fig. 4A) $20.96 \mathrm{~mm}$ long, heavily covered with dark spots creating bands on head, coxae, pereon, and pleon. Eye black. Antenna 1 (Fig. 4B) about 0.7 times as long as body; peduncular article 1 with 2 spines on posterior margin; peduncular article 2 slightly longer than article 1 . Peduncular article 4 of antenna 2 (Fig. 4C) slender, nearly identical to article 5 in length. Peduncular article 2 of antenna 1 reaching nearly to end portion of article 4 of antenna 2 .

Upper lip (Fig. 4D) broadened, with ventral margin rounded. Right incisor of mandible (Fig. 4F) with 8 teeth, left incisor (Fig. 4E) with 7 teeth; right lacinia mobilis with 5 teeth, left lacinia mobilis with 5 teeth; bearing 10 right raker spines and 10 left raker spines; molar well developed, triturative, bearing 1 seta; article 3 of palp longer than article 2 . Apical lobe of outer lobe in lower lip (Fig. 4G) about 1.3 times as long as medial lobe and both lobes separated.

Inner plate of maxilla 1 (Fig. $4 \mathrm{H}$ ) having 1 seta; outer plate with 10 apical spines; article 2 of palp with 8 apicomedial spines and 4 subterminal setae. Inner plate of maxilla 2 (Fig. 4I) narrowed; outer plate broader.

Outer plate of maxilliped (Fig. 4J) having 21 teeth; article 1 of palp identical to article 3 in length, article 4 bearing 1 seta on inner margin.

Gnathopod 1 (Fig. 5A) subchelate; coxa wider than deep, with anteroventral margin slightly produced; basis expanded, having anterodistal lobe; merus 2 times as long as ischium, bearing posteromarginal setae; carpus about 1.4 times as long as propodus, having posterodistal lobe; propodus ovoid; palm oblique; dactylus small.

Carpus and propodus of gnathopod 1 with numerous plumose setae on both anterior and posterior margin. Gnathopod 2 (Fig. 5B) chelate; coxa subrectangular; basis having anterodistal lobe; ischium having anterodistal lobe; merus slightly shorter than carpus; carpus having subrectangular lobe on posterior margin; propodus subrectangular, about 2.3 times as long as carpus, with posterior margin extended; palm transverse, having sloped quadrate hump and with tooth on posterodistal corner; dactylus robust and curved.

Pereopods 3 (Fig. 5C) and 4 (Fig. 5D) nearly identical in shape. Coxa of pereopod 3 deeper than wide, with anterodistal margin rounded; ischium about 0.5 times as long as carpus; carpus and propodus identical in length. Basis of pereopod 5 (Fig. 5E) ovoid; merus shorter than propodus; carpus about 2 times as long as ischium; propodus about 1.6 times as long as carpus, bearing spines on posterior margin. Pereopods 6 (Fig. 5F) and 7 (Fig. 5G) nearly identical in shape. Basis of pereopod 7 expanded to proximal part, bearing spines on anterior margin, and posteroventral corner with 1 spine; merus about 2.7 times as long as ischium; carpus

\footnotetext{
$1 *$ 네모손참옆새우 (신칭)
} 


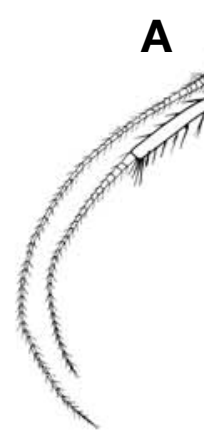

A
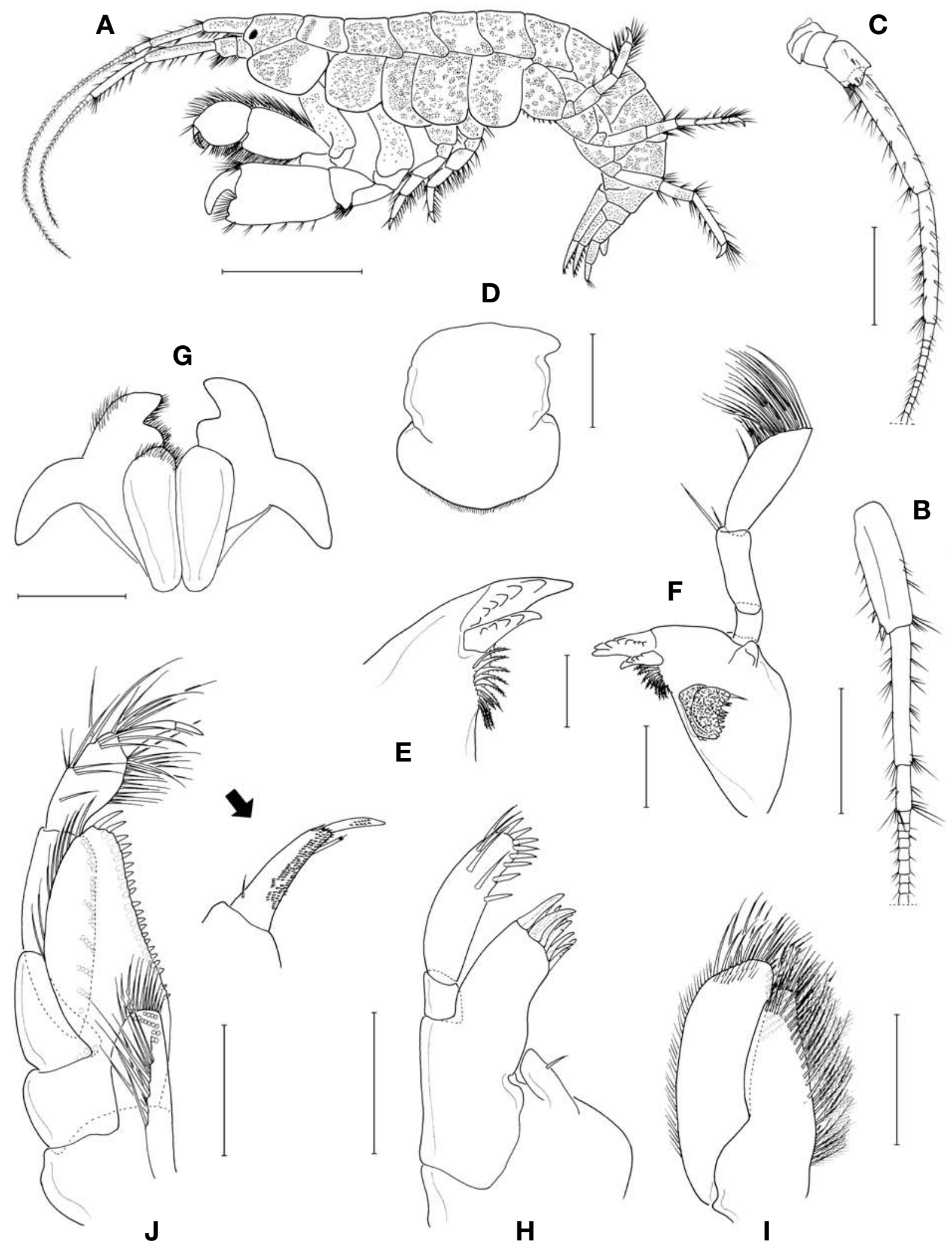

Fig. 4. Ampithoe tarasovi Bulycheva, male. $A$, body; $B$, antenna $1 ; C$, antenna $2 ; D$, upper lip; $E$, left mandible; $F$, right mandible; G, lower lip; H, maxilla 1; I, maxilla 2; J, maxilliped. Scales: A, 4 mm; B, C, 2 mm; D, F-J, 0.5 mm; E, $0.25 \mathrm{~mm}$. 


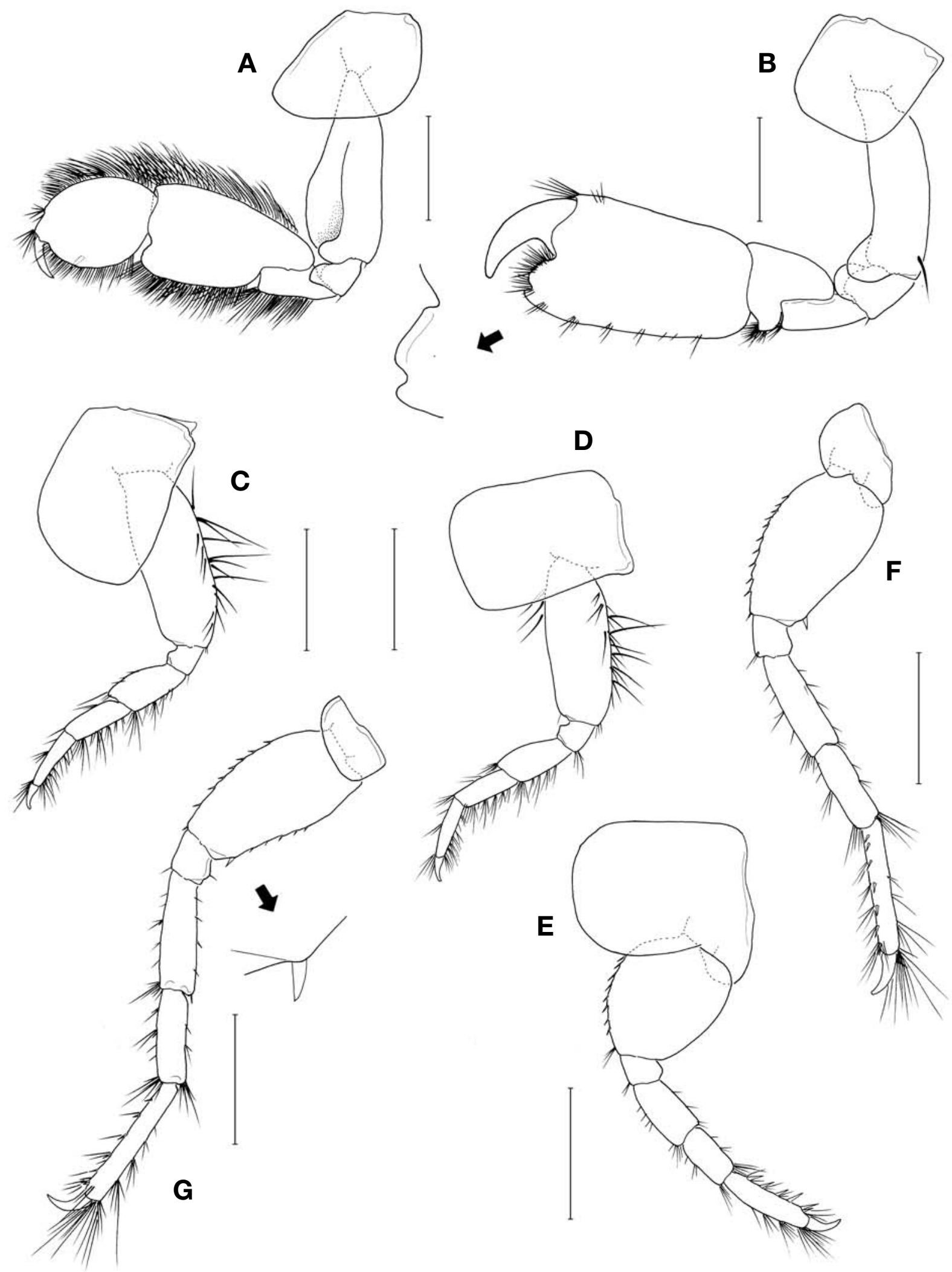

Fig. 5. Ampithoe tarasovi Bulycheva, male. A, gnathopod 1; B, gnathopod 2; C, pereopod 3; D, pereopod 4; E, pereopod 5; F, pereopod 6; G, pereopod 7. Scales: A-G, $2 \mathrm{~mm}$. 

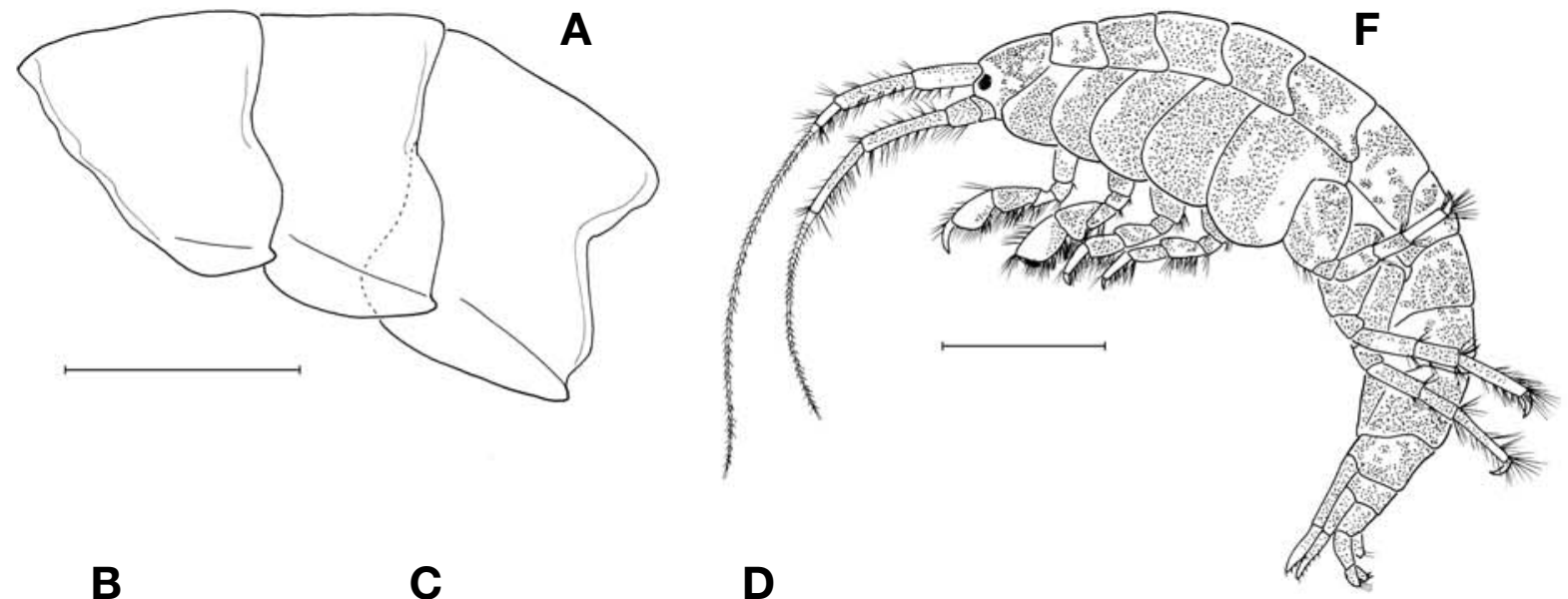

B

C
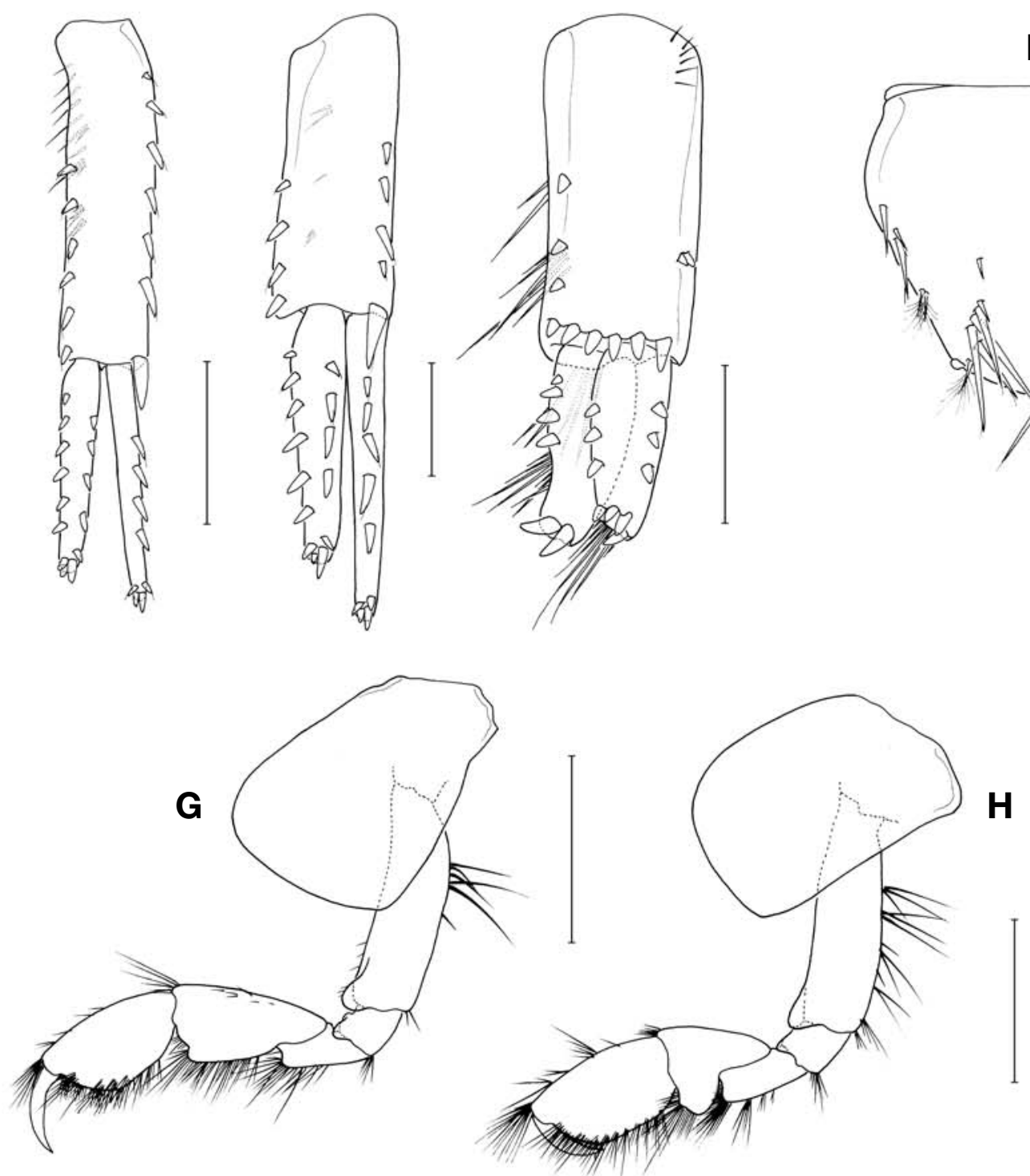

E
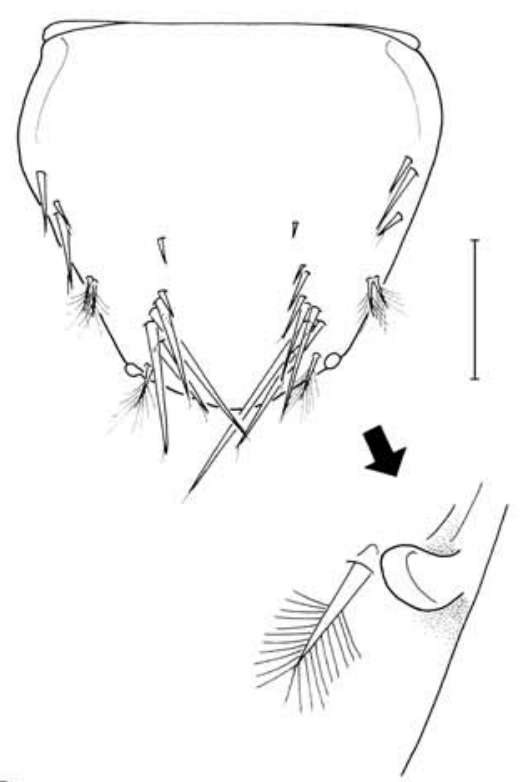

Fig. 6. Ampithoe tarasovi Bulycheva, male. A, epimera 1-3; B, uropod 1 ; C, uropod 2; D, uropod 3; E, telson. Female. F, body; G, gnathopod 1; H, gnathopod 2. Scales: A, G, H, $2 \mathrm{~mm} ; B, 1 \mathrm{~mm} ; \mathrm{C}, \mathrm{D}, 0.5 \mathrm{~mm} ; \mathrm{E}, 0.25 \mathrm{~mm} ; \mathrm{F}, 5 \mathrm{~mm}$. 
shorter than merus; propodus about 1.5 times as long as carpus, bearing spines on anterior margin.

Epimera 1-3 (Fig. 6A) with lateral ridge; epimeron 1 rounded posterodistally, having tooth on posteroventral angle; epimera 2 and 3 subrounded posterodistally, with ventral margin evenly curved, having rounded tooth on each posteroventral angle.

Uropod 1 (Fig. 6B) with peduncle about 1.5 times as long as rami; inner ramus longer than outer ramus. Uropod 2 (Fig. 6C) with peduncle identical to inner ramus in length; inner ramus longer than outer ramus. Peduncle of uropod 3 (Fig. 6D) approximately 2 times as long as rami, bearing 3 dorsal, 5 distal, and 2 ventral spines; inner ramus nearly identical to outer ramus in length, bearing 3 spines on both dorsal and ventral margin and 4 apical spines; outer ramus with 2 hooklike apical spines and 4 dorsal spines.

Telson (Fig. 6E) entire, broader than long, gradually narrowed distally and nearly truncated, having 4 long and 2-4 short setae on subapical part and 3 smooth and 2 small plumose setae on both sides; telsonic cusps rounded hook-shape, with 1 plumose seta.

Female. Body (Fig. 6F) $25.44 \mathrm{~mm}$ long, slightly larger than that of male.

Gnathopod 1 (Fig. 6G) subchelate; coxa deeper than wide, with anteroventral margin produced and rounded; basis slender, having anterodistal lobe; merus about 0.6 times as long as propodus; carpus broadened distally, having small posterodistal lobe; propodus subrectangular, about 0.9 times as long as carpus; palm oblique; dactylus slightly overreaching palm. Gnathopod 2 (Fig. 6H) subchelate; coxa deeper than wide; merus shorter than carpus; propodus subrectangular, about 1.3 times as long as carpus; palm oblique; dactylus reaching corner of palm.

Remarks. Kim and Kim (1987) recorded Ampithoe lacertosa Bate, 1858 for the first time from Jejudo Island in Korea. However, Kim and Kim's description of A. lacertosa agrees with the original description of $A$. tarasovi Bulycheva, 1952 except for the following characteristics: the length of carpus and propodus is nearly equal in male gnathopod 1 . However, judging from Fig. 2C of Kim and Kim (1987) and Fig. 2A of Kim and Kim (1988), the propodus is far shorter than carpus. Thus the description part of gnathopod 1 in Kim and Kim (1987) seems to be a mistake. We accordingly consider $A$. lacertosa described by Kim and Kim (1988) as A. tarasovi.

The characteristics of the present specimens coincide with that of the original description provide by Bulycheva (1952) based on individuals from the Sea of Japan in having the following features: the apical and medial lobes of outer lobe are separated in the lower lip, the carpus of male gnathopod 1 is about 1.4 times as long as the propodus, the palm of the male gnathopod 2 has a sloped quadrate hump and a postero- distal tooth, the peduncle of uropod 3 is approximately 2 times as long as the rami, and the length of the carpus is longer than that of the propodus of female gnathopod 1. Bulycheva (1952) noted that $A$. tarasovi is very abundant in the northern region of the Sea of Japan and in Petra Velikogo Bay in Russia.

Distribution. Korea (current study), Japan, and Russia.

Ecological notes. It has been established that members of the family Ampithoidae live in self-constructed tube-like houses in coastal marine algae (Conlan and Bousfield, 1982). They construct tube-like houses on the surface of macroalgae between neighboring blades using detritus, algal fragments, and fecal pellets (Appadoo and Myers, 2003). We observed tube-building behavior in Ampithoe tarasovi. This species constructed a cylindrical tube made of amphipod silk and detritus by folding algae.

\section{DISCUSSION}

It is inferred that Ampithoe tarasovi has been misidentifed as A. lacertosa in Korea (Kim and Kim, 1987, 1988) for the following two reasons. First, they have extremely similar morphology with the exception of a few appendages. Second, they share the same habitats and are collected frequently from identical localities. Hitherto, A. tarasovi was recorded by a Russian researcher and they have been known to be distributed only in Sea of Japan and in Petra Velikogo Bay. Although it has been validated as a species, it has not been recorded in other regions. Accordingly, the presence of $A$. tarasovi may have been overlooked in Korea. The current study offers the information of the two species including clear taxonomic traits by presenting detailed descriptions and illustrations, which will enable accurate identification of both species.

\section{ACKNOWLEDGEMENTS}

The present study was supported by a grant from Marine Biotechnology Programme funded by Ministry of Land, Transport and Maritime affairs of the Korean Government.

\section{REFERENCES}

Appadoo, C. and A.A. Myers, 2003. Observations on the tubebuilding behavior of the marine amphipod Cymadusa filosa Savigny (Crustacea: Ampithoidae). J. Nat. Hist., 37(18): 2151-2164.

Barnard, J.L., 1954. Marine Amphipoda of Oregon. Oregon State Monographs, Stud. Zool., 8: 1-103. 
Barnard, J.L., 1965. Marine Amphipoda of the family Ampithoidae from Southern California. Proc. U. S. Nat. Mus., 118(3522): 1-46.

Barnard, J.L. and G.S. Karaman, 1991. The families and genera of marine gammaridean Amphipoda (except marine gammaroids). Rec. Austr. Mus. Suppl., 13: 1-866.

Bate, C.S., 1858. On some new genera and species of Crustacea Amphipoda. Ann. Mag. Nat. Hist., ser. 3, 1: 361-362.

Bate, C.S., 1862. Catalogue of the specimens of amphipodous Crustacea in the collection of the British Museum, London, pp. 1-399.

Bulycheva, A.I., 1952. Novue vidy bokoplavov (Amphipoda, Gammaridea) iz Japonskogo Morja. Akad. Nauk SSSR. Trudy Zool. Inst., 12: 195-250.

Conlan, K.E. and E.L. Bousfield, 1982. The amphipod superfamily Corophioidea in the Northeastern Pacific region. Family Ampithoidae: Systematics and distributional ecology. Publ. Biol. Oceanogr., Nat. Mus. Canada, 10: 41-75.

Gurjanova, E.F., 1951. Bokoplavy morej SSSR i sopredel'nykh vod (Amphipoda, Gmmaridea). Akad. Nauk SSSR, Opred. Faune SSSR, 41: 1-1029.

Kim, H.S. and C.B. Kim, 1987. Marine gammaridean Amphipoda (Crustacea) of Cheju Island and its adjacent waters, Korea. Korean J. Syst. Zool., 3(1): 1-23.

Kim, H.S. and C.B. Kim, 1988. Marine gammaridean Amphi- poda (Crustacea) of the family Ampithoidae from Korea. Korean J. Syst. Zool., Special Issue, 2: 107-134.

Kim, Y.H., Y. Eun and K.S. Lee, 2005. Amphipods (Gammaridea and Caprellidea) fauna of Jindo Island in Korea. Korean J. Syst. Zool., Special Issue, 5: 1-11.

Nagata, K., 1960. Preliminary notes on benthic Gammaridean Amphipoda from the Zostera region of Mihara Bay, Seto Inland Sea, Japan. Pulb. Seto Mar. Biol. Lab., 8(1): 163182.

Peart, R.A., 2007. A review of the Australian species of Ampithoe Leach, 1814 (Crustacea: Amphipoda: Ampithoidae) with descriptions of seventeen new species. Zootaxa, 1566: $1-95$.

Poore, A.G.B., N.A. Hill and E.E. Sotka, 2008. Phylogenetic and geographic variation in host breadth and composition by herbivorous amphipods in the family Ampithoidae. Evolution, 62: 21-38.

Stephensen, K., 1944. Some Japanese amphipods. Vidensk. Medd. Dansk Natuth. For., 108: 25-88.

Tzvetkova, N.L., 1967. K faune ekologii bokoplavov (Amphipoda, Gammaridea) Zaliva Poc'et (Japonskoe More). Akad. Nauk SSSR, Zool. Inst., Issled. Fauny Morei, 5: 160-195.

Received October 23, 2010 Accepted November 12, 2010 